\title{
COMPARISON OF TWO DRY FRACTIONATION PROCESSES FOR PROTEIN ENRICHMENT OF SUNFLOWER MEAL
}

\author{
Strahinja Ž. Vidosavljević ${ }^{* 1}$, Nemanja Đ. Bojanić ${ }^{2}$, Viktor $Đ$. Stojkov ${ }^{1}$, \\ Radmilo R. Čolović ${ }^{1}$, Olivera M. Đuragić ${ }^{1}$, Aleksandar Z. Fišteš² ${ }^{2}$, Vojislav V. Banjac ${ }^{1}$ \\ ${ }^{1}$ University of Novi Sad, Institute of Food Technology, 21000 Novi Sad, Bulevar cara Lazara 1, Serbia \\ ${ }^{2}$ University of Novi Sad, Faculty of Technology, 21000 Novi Sad, Bulevar cara Lazara 1, Serbia
}

\begin{abstract}
Sunflower meal, a by-product of oil extraction from sunflower seeds, is an important protein source in domestic as well as European feed industry. There is a common interest for the proper utilization of sunflower meal and for the development of an effective fractionation process in order to obtain a nutritionally improved sunflower meal. This paper proposes and compares two dry fractionation processes for the improvement of sunflower meal protein content on a laboratory scale. The first phase of both processes included two step milling using a hammer and roller mill. In the second phase, the ground sunflower meal was fractionated by sieving or by air classification. Results indicated that the implementation of any of the suggested processes improved protein content of the starting sunflower meal to a level sufficient to categorize it as "high-protein" according to current national regulation on animal feed quality, with the fraction yields over $50 \%$. For the air classification process the most promising result was achieved for air flow of $7 \mathrm{~m}^{3} / \mathrm{h}(12.8 \%$ relative protein enrichment, $56.42 \%$ fraction yield). For the fractionation process with sieving as a separation step, when fractions smaller than $350 \mu \mathrm{m}$ were conjoined, relative protein enrichment of $28.5 \%$ and fraction yield of $51.17 \%$ were achieved. The high protein content $(48.81 \%$ on dry basis) of the joined fraction enables enough space for optimizing the protein content - fraction yield ratio of obtained sunflower meal. By applying sieves with larger aperture, it is possible to obtain higher yields of sunflower meal categorized as high-protein on account of a slight decrease in protein content, which gives this process a certain flexibility and potential for application on a larger scale.
\end{abstract}

Key words: sunflower meal, protein content, fraction yield, dry fractionation, sieving, air classification

\section{INTRODUCTION}

Constant growth of the global population elevates pressure on the livestock sector to meet the growing demand for animal protein supply. Expanded and more efficient use of the plant-based proteins could be an important step towards sustainable food production (Aiking, 2011). Although plant proteins could be obtained from various sources, soybean meal has been the most important source of high quality vegetable proteins ( $\mathrm{Kim}$ et al., 2019) and represents a standard to which other proteins are compared (Green and Kiener, 1989; Cromwell, 1999; Đorđević and Dinić, 2011). Soybean meal is characterized by low fiber content, high protein content and its optimal amino acid composition, as well as an especially high content of lysine that is the most limiting amino acid in grains (Dale, 1996). However, the use of soybean meal has also several disadvantages. Due to the presence of antinutritional substances, the preparation of soybean meal requires heat 
treatment which has to be conducted properly in order to avoid undesirable reduction of protein functionality (Yasothai, 2016). Soybean meal is also the number one genetically modified crop in the world and GMO products are not authorized in every country, especially in Europe. Besides that, the lack of appropriate climatic conditions for growing soybeans in Europe leads to insufficient production, and many European countries are forced to import this protein-rich feedstock (Taelman et al., 2015; Kim et al., 2019). The aforementioned significantly impacts the final costs of soybean meal and the interest for alternative, more economical sources of proteins is rapidly growing.

Sunflower meal (SFM), a by-product of oil extraction from sunflower seeds, is a relatively inexpensive source of protein. Sunflower is a major oilseed in Serbia with an annual production of approximately $734,000 \mathrm{t}$ in 2018 (SORS, 2019) making the SFM important and widely used feedstuff. The protein content of SFM is high and usually varies from 29 to 34\% (Ramachandran et al., 2007; Geneau-Sbartaï et al., 2008). In comparison to soybeans, SFM contains less antinutritional factors and has a similar amino acid composition but also a lower amount of lysine (Canibe et al., 1999; Ramachandran et al., 2007; Mérida et al., 2010). Therefore, for the use of sunflower meal as a high protein ingredient in animal diet formulations, an additional amount of lysine is required to be added (Lević and Sredanović, 1997; Senkoylu and Dale, 1999; Banjac et al., 2018). SFM is also characterized by very high fiber content (18-23\%) which presents the most apparent disadvantage and the limiting factor for the wider usage of SFM in diet formulations, especially for monogastric animals. Thanks to inversely correlated contents of fiber and protein in SFM, fiber level could be decreased and protein increased by separation of hulls from SFM using different fractionation processes. Since the SFM is an important protein source in the Serbian and European feed industry there is a common interest for the proper utilization of SFM and for the development of an effective fractionation process in order to gain nutrition- nally improved sunflower meal characterrized by low fiber and high protein content.

In order to obtain plant-derived protein ingredients, many conventional methods have been developed. The wet fractionation processes are the most commonly used technologies due to the capability to produce relatively pure protein isolates from different plant resources (Boye et al., 2010; Jayasena et al., 2011; Kachrimanidou et al., 2015). These conventional processes may also be used for obtaining protein concentrates from SFM (Lovatto et al., 2015). However, wet fractionation techniques have a lot of disadvantages such as high consumption of water and energy, as well as the use of harsh conditions during processing, which adversely affects the quality and functionality of ingredients (Schutyser and Van der Goot, 2011). Therefore, much attention has been given to the development of more sustainable dry fractionation approaches in order to produce protein fractions of less purity but with preserved native functionalities. Dry fractionation processes produce signifycantly less waste compared to the wet counterparts since there are no water effluents. To obtain valuable fractions from different plant materials, various dry fractionation methods such as sieving, air classification, centrifugal and electrostatic separation, have been used (Sredanovic, 2007; Srinivasan and Columbus, 2009; Pandya and Srinivasan, 2012; Wang et al.,2016; Tabtabaei et al., 2017). Furthermore, some authors have been proposed different dry fractionation processes in order to obtain nutritionally improved SFM fraction with noteworthy results (Draganov, 2015; Banjac et al., 2017). Draganov (2015) recently invented a fractionation process which is consisted of several successive grinding and sieving steps. This multistep process, that included the use of roller mill for grinding of coarse material, allows preparing SFM fractions with protein content higher than $50 \%$ and yields acceptable on industrial scale. Banjac et al. (2017) applied the two-step process which combined the first grinding of SFM and subsequent air classifying of previously ground SFM. To the best of our knowledge, this method provides the 
highest relative protein enrichment, in comparison to any other process of SFM dry fractionation so far. Unfortunately, a drawback of this method is obtaining the low fraction yields that could limit this process to attain wider application in the industry.

Based on previous investigations (Draganov, 2015; Banjac et al., 2017), in this study, two fractionation processes of SFM are proposed and compared on a laboratory scale. The aim of this research was: 1) to investigate feasibility of obtaining high protein fractions with satisfactory yield by combination of SFM grinding and subsequent fractionation by a zig-zag air classifier and 2) to determine if the zig-zag air classification is more effective than the sieving process.

\section{MATERIALS AND METHODS}

\section{Material}

Sunflower meal (SFM), purchased from the oil factory "Victoria Oil", Šid, Serbia, was used in this experiment as a starting material and its chemical composition is presented in Table 1.

Table 1.

Chemical composition of starting SFM

\begin{tabular}{lc}
\hline Chemical composition & Content (\%) \\
\hline Moisture & 6.96 \\
Crude protein & $37.99^{*}$ \\
Crude fiber & $16.36^{*}$ \\
\hline${ }^{*}$ calculated on dry matter basis &
\end{tabular}

\section{Milling and fractionation of SFM}

For crushing of agglomerates that were normally present in the starting sunflower meal, a hammer mill (ABC Engineering Pančevo, Serbia) equipped with $6 \mathrm{~mm}$ sieve was used. Such coarsely ground SFM (HM-SFM) was additionally milled using a laboratory roller mill (model S-150 $\mathrm{M})$ equipped with four corrugated rolls positioned to form three milling passages, to obtain material marked as LRM-SFM.

LRM-SFM was then fractionated either by sieving or by air classification process. The whole process of grinding and fractionation is schematically presented in Figure 1. Sieving of LRM-SFM was performed on a Bühler laboratory sifter (model MLU 300 , Uzwil, Switzerland) with rubber balls placed in each sieve to facilitate particle separation and to clean the sieves. For separation into four fractions during $3 \mathrm{mi}-$ nutes of sieving time, square aperture sieves of size: $350 \mu \mathrm{m}, 250 \mu \mathrm{m}, 150 \mu \mathrm{m}$, along with the bottom collecting pan, were used (fractions $S_{1}, S_{2}, S_{3}$ and $S_{4}$, respectively). In all of the four fractions, moisture and protein content were determined. Yields $y_{\mathrm{i}}(\%)$ of the obtained fractions were calculated using the following equation:

$$
y_{i}=\frac{m_{i}}{m_{t}} \times 100
$$

where $m_{i}(g)$ is the mass of $i_{\text {th }}$ fraction and $m_{t}(g)$ is the whole mass of the sieved sample. Estimated protein content value of joined fraction $\mathrm{p}_{2-4}(\%)$ (three joined fractions S2, S3 and S4) was calculated according to the formula:

$$
p_{2-4}=\frac{y_{2} p_{2}+y_{3} p_{3}+y_{4} p_{4}}{y_{2}+y_{3}+y_{4}}
$$

where $y_{\mathrm{i}}(\%)$ and $\mathrm{p}_{\mathrm{i}}(\%)$ are the yield and determined protein content of $\mathrm{i}_{\text {th }}$ fraction, respectively.

Air classification of LRM-SFM was conducted using a laboratory zig-zag air classifier (1-40 MZM, Hosokawa Alpine, Augsburg, Germany). Air flow rate was varied at $4,5,6,7$ and $8 \mathrm{~m}^{3} / \mathrm{h}$ while Bowl feeder oscillation rate (BFOR) was set at $80 \%$ as Banjac et al. (2017) determined that this parameter does not have a significant influence on protein enrichment level. Yields of the obtained fractions were calculated using the following equations:

$$
\begin{aligned}
& y_{c}=\frac{C}{C+F} \times 100 \\
& y_{f}=\frac{F}{C+F} \times 100
\end{aligned}
$$

where $C(g), F(g), y_{c}(\%)$ and $y_{f}(\%)$ represent the mass of coarse fraction, the mass of fine fraction, yield of coarse fraction and yield of fine fraction, respectively. All eight samples (four coarse and four fine fractions) obtained using four different air flow rates were analyzed for moisture and crude protein content. 


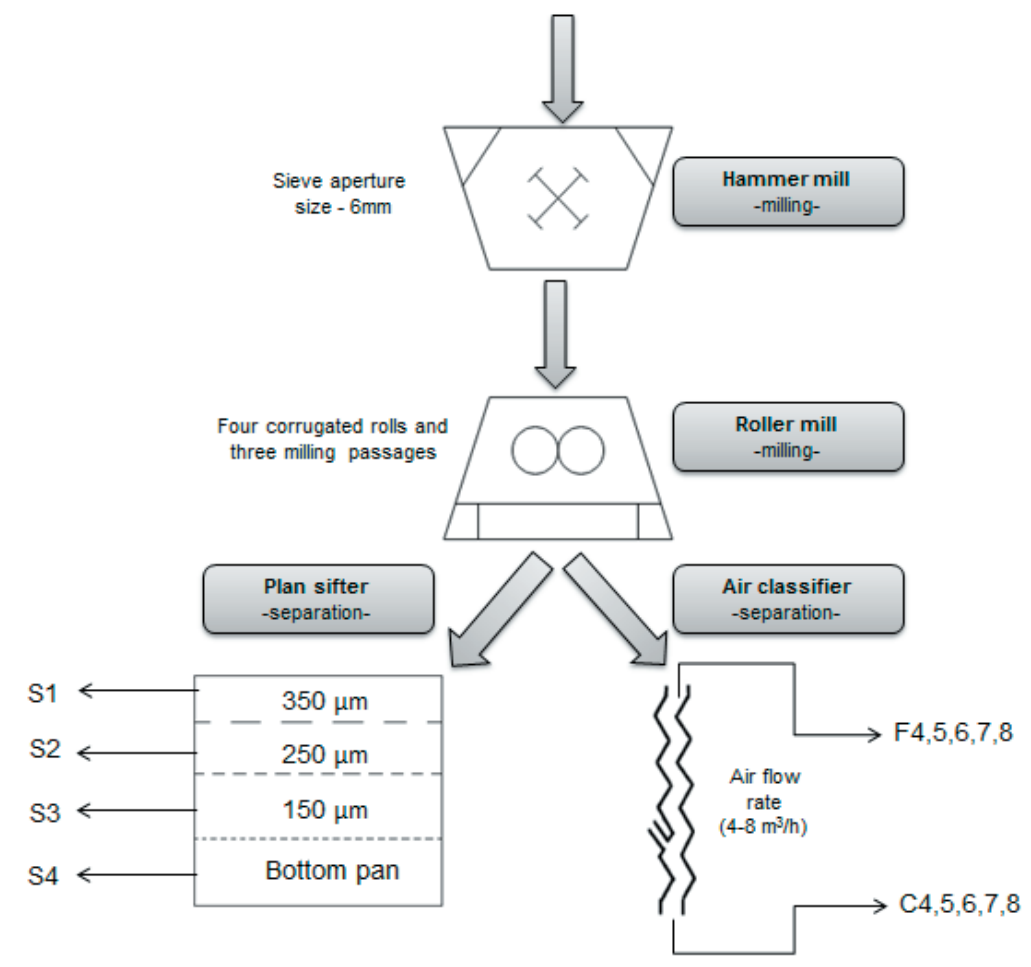

Figure1. Schematic presentation of fractionation processes compared in this study

Crude protein, crude fiber and moisture content were analyzed according to AOAC methods (AOAC, 1998). Particle size distribution was determined by standard sieving analysis (ISO 2591-1, 1998) in duplicate, using laboratory sieves with sieve's openings ranging from 63 to 3550 $\mu \mathrm{m}$ (AS200 control, Retch $\mathrm{GmbH}$, Haan, Germany). The geometric mean diameter (GMD) was determined according to the ASAE standard (ASAE standard 319.3, 2006).

\section{Statistical analysis}

One-way ANOVA and Tukey's Honestly Significant Difference test were used to analyze variations of the results. Differences between the means with probability $p<0.05$ were accepted as statistically significant and differences between the means with $0.05<p<0.10$ were accepted as tendencies towards differences. The level of confidence was set at $95 \%$ (STATISTICA v.13.5.0.17, 2018).

\section{RESULTS AND DISCUSSION}

\section{Milling process}

SFM obtained as a by-product of sunflower oil extraction, normally contains SFM obtained as a by-product of sunflower oil extraction, normally contains ag-glomerates made of kernels and hulls adhered to them (Sredanović et al., 2011; Banjac et al., 2013). Hammer mill was used in order to crush existing agglomerates and to enable subsequent milling by roller mill. Crushing efficiency of hammer mill and milling efficiency of roller mill were assessed comparing particle size distribution before and after milling pro-cesses (Figure 2 ). It can be noticed from Figure 2 that hammer meal efficiently crushed present agglomerates (particle larger than 3550 $\mu \mathrm{m})$, reducing their content from $24.7 \%$ in starting SFM to less than $1 \%$ in HM-SFM, and almost halved the GMD of SFM from 1262.1 to 644.2 of HM-SFM. Subsequent use of roller mill also had a great impact on the particle size distribution of SFM. Namely, roller mill completely eliminated fractions of particle size larger than 2000 $\mu \mathrm{m}$ that were pre-sent in HM-SFM and reduced GMD of HM-SFM from 644.2 to $421.4 \mu \mathrm{m}$ that was calculated for LRMSFM.

The HM-SFM was composed predominantly of $250-630 \mu \mathrm{m}$ fraction and roller mill succeeded to even more increase percentage of the same fraction from 31.9 in HM-SFM up to $51.6 \%$ in LRM-SFM. 


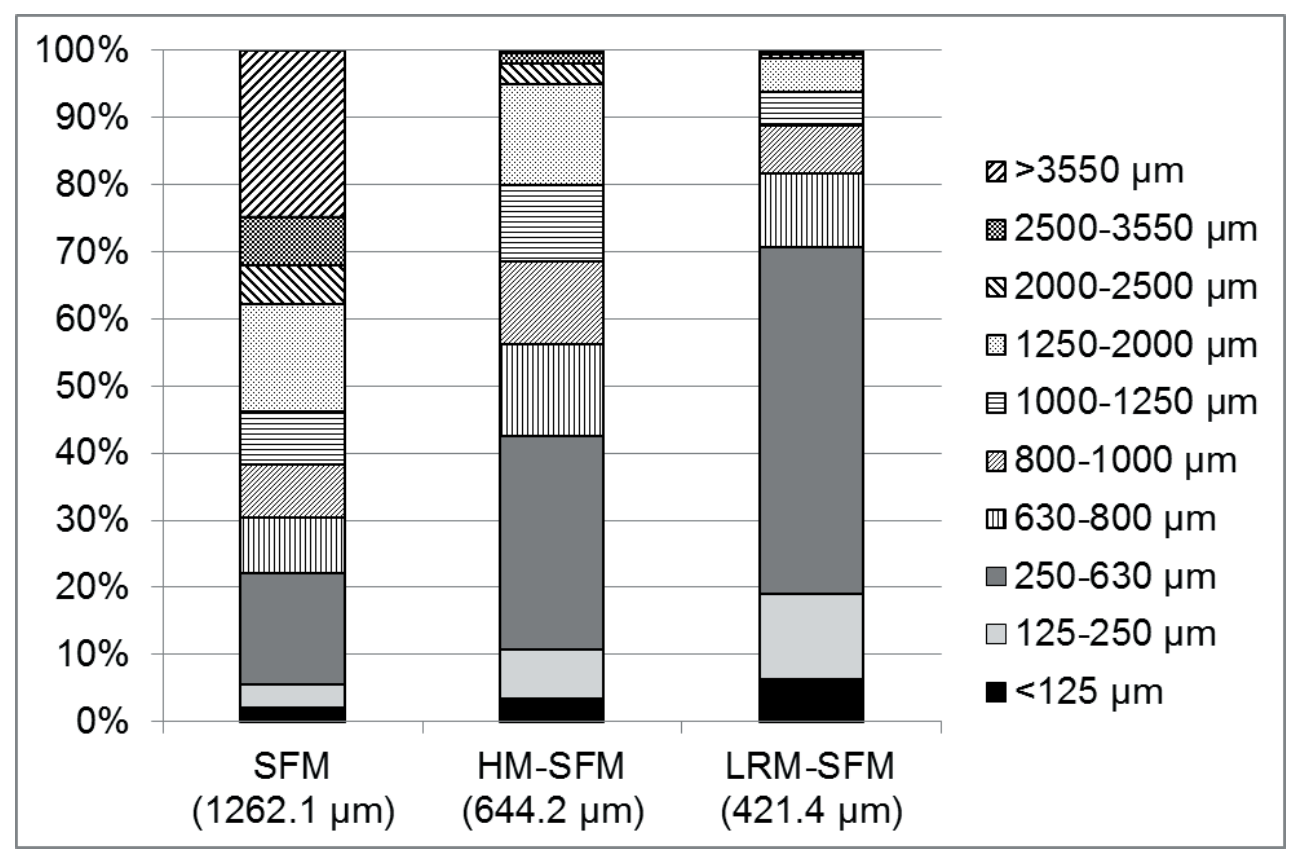

Figure 2. The particle size distribution of starting (SFM), coarsely milled (HM-SFM) and fine milled (LRM-SFM) sunflower meal

This is similar with findings from the study of Banjac et al. (2017) where hammer mill was used for the milling of SFM and all three sieves, with different sieve opening diameters $(3 \mathrm{~mm}, 2 \mathrm{~mm}$ and $1 \mathrm{~mm})$ that were used, provided the ground SFM that had most particles in a size range between 250 and $630 \mu \mathrm{m}$.

\section{Fractionation processes}

LRM-SFM, milled in a previously two-step milling process, was then fractionated by air classification and sieving. The results obtained with both methods are presented separately and subsequently compared.

\section{Air classification}

The results of the air classification process are presented in Table 2. Based on the results obtained in the previous study (Banjac et al., 2017), it was expected that using a laboratory zig-zag air classifier will provide coarse fractions rich in proteins. However, the obtained results showed that air classification process of LRM-SFM decreased the protein content of coarse fraction and increased the protein content of fine fractions. Similar to this was observed in the research paper of Laudadio et al. (2013), where the use of turboclassifier for the fractionation of micronized
SFM also provided fine fractions with increased protein content. The GMD of LRM-SFM was similar to that obtained in the investigations of Banjac et al. (2017) when a hammer mill equipped with $2 \mathrm{~mm}$ sieve was used for grinding SFM $(453.1 \mu \mathrm{m})$. The authors managed to obtain protein-enriched coarse fractions using zig-zag classifier for air flows of 8.7 and $12.5 \mathrm{~m}^{3} / \mathrm{h}$, and stated that the particle size was probably not the reason for obtaining protein enriched fractions in their research, but the difference in size between kernels and hulls. Maaroufi et al. (2000) concluded that the higher elasticity of hulls is the reason why hull particles of the pea were coarser than kernel particles. Therefore, it is possible that, similarly to the pea hulls, higher elastic properties of SFM hulls enable them to pass through the rollers only pressed and almost unchanged in size during milling.

This difference in physical properties of hulls compared to kernels, enables air classifier to separate them as a coarse fraction, which is pulled down by gravity. Since the aim of this work was to improve the protein content of SFM, only the change of protein content in the fine fractions was discussed. 
Table 2.

Yield and protein content of air classified fractions

\begin{tabular}{ccccc}
\hline \multirow{2}{*}{$\begin{array}{c}\text { Air flow rate } \\
\left(\mathbf{m}^{3} / \mathbf{h}\right)\end{array}$} & \multicolumn{2}{c}{ Fraction yield $(\%)$} & \multicolumn{2}{c}{ Protein content $(\%$ dry basis) } \\
\cline { 2 - 5 } & Fine & Coarse & Fine & Coarse \\
\hline 4 & 20.77 & 79.23 & $40.67 \pm 0.40^{\text {at }}$ & $38.40 \pm 0.28^{\mathrm{a}}$ \\
5 & 38.72 & 61.28 & $42.60 \pm 0.56^{\mathrm{b} t}$ & $33.65 \pm 0.09^{\mathrm{b} t}$ \\
6 & 42.56 & 57.44 & $41.03 \pm 0.04^{\mathrm{a} \dagger}$ & $34.12 \pm 0.43^{\mathrm{b} t}$ \\
7 & 56.42 & 43.58 & $42.85 \pm 0.14^{\mathrm{b} t}$ & $30.29 \pm 0.13^{\mathrm{c} t}$ \\
8 & 65.40 & 34.60 & $38.06 \pm 0.27^{\mathrm{c}}$ & $35.29 \pm 0.21^{\mathrm{d} \dagger}$
\end{tabular}

a, - Values with different letters in the same column are significantly different $(p<0.05)$

$t$-Means are significantly different compared to the unclassified meal $(p<0.05)$

Table 3.

Yield and protein content of sieved fractions

\begin{tabular}{|c|c|c|c|}
\hline Sieving fraction & Fraction size $(\mu \mathrm{m})$ & Yield (\%) & $\begin{array}{c}\text { Crude protein content } \\
\text { (\% dry basis) }\end{array}$ \\
\hline$S_{1}$ & $>350$ & 48.83 & $27.98 \pm 0.16^{\text {at }}$ \\
\hline $\mathrm{S}_{2}$ & $350 / 250$ & 18.12 & $49.71 \pm 0.05^{\mathrm{b} t}$ \\
\hline $\mathrm{S}_{3}$ & $250 / 150$ & 18.12 & $47.70 \pm 0.08^{c t}$ \\
\hline $\mathrm{S}_{4}$ & $<150$ & 14.93 & $49.06 \pm 0.06^{\mathrm{d} t}$ \\
\hline $\begin{array}{l}\text { Joined fraction } \\
\left(\mathrm{S}_{2}-\mathrm{S}_{4}\right)\end{array}$ & $<350$ & $51.17^{*}$ & $48.81^{*}$ \\
\hline
\end{tabular}

An increase in airflow from 4 to $7 \mathrm{~m}^{3} / \mathrm{h}$ resulted in a significant increase $(p<0.05)$ of protein content in fine fractions compared to the unclassified meal. On the other hand, the highest air flow $\left(8 \mathrm{~m}^{3} / \mathrm{h}\right)$ was unable to significantly improve $(p<0.05)$ protein content of unclassified SFM. This is due to high air velocity that was strong enough to drag up more of the larger hulls particles and subsequently to increase the yield of the obtained fine fraction, but not the protein content. The highest protein content of fractions was obtained at 5 and $7 \mathrm{~m}^{3} / \mathrm{h} \quad(42.60$ and $42.85 \%$, respectively).

These fractions did not significantly differ $(p<0.05)$ in protein content. However, the air flow of $7 \mathrm{~m}^{3} / \mathrm{h}$ resulted in a considerably higher fraction yield (56.42\%) which makes this air flow a far better choice for the fractionation of LRM-SFM than that at $5 \mathrm{~m}^{3} / \mathrm{h}$.

\section{Sieving}

The results of LRM-SFM fractionation by sieving are shown in Table 3. All fractions obtained by sieving had significantly different $(p<0.05)$ crude protein content. Moreover, the crude protein content was significantly different comparing to the starting SFM. As explained, the reason why the coarsest fraction $\left(S_{1}\right)$ had significantly lower $(p<0.05)$ crude protein content $(27.98 \%)$ compared to the starting SFM was the difference in size of kernels and hulls. Hulls, being tough and fibrous, passed through the grinding zones of roller mill, with low reduction or without a reduction in size at all, remained as overtails on the coarsest sieve $(350 \mu \mathrm{m})$. On the other hand, fine fractions $S_{2}, S_{3}$ and $S_{4}$ had significantly higher $(p<0.05)$ crude protein content $(49.71 ; 47.70$ and $49.06 \%$, respectively) compared to the starting SFM and the coarsest fraction $S_{1}$, but also had a far lower fractions yield (18.12; 18.12 and $14.93 \%$, respectively). Since the yields of these three high protein fractions were not satisfactory, in order to obtain higher yield it is possible to join these fractions in one fraction $\left(S_{2}-S_{4}\right)$ without negative impact on the protein content. 
The calculation showed that bringing together fractions $S_{2}, S_{3}$ and $S_{4}$, all with particles bellow $350 \mu \mathrm{m}$, would result in a fine fraction with increased yield up to $51.17 \%$ and markedly high protein content of $48.81 \%$ (Table 3 ).

\section{Comparison of fractionation methods}

Air classification process, for the trial where air flow of $7 \mathrm{~m}^{3} / \mathrm{h}$ was used, provided relative protein enrichment of $12.8 \%$ and a high fraction yield of $56.42 \%$. The yield of theoretically joined $\left(\mathrm{S}_{2}-\mathrm{S}_{4}\right)$ fraction obtained by sieving was somewhat lower $(51.17 \%)$, but the relative protein enrichment was by far higher $(28.5 \%)$. For comparison, Laudidio et. al. (2013) obtained lower relative protein enrichment $(20.1 \%)$ of SFM with a much higher fraction yield $(87.9 \%)$ when air classification of the previously micronized SFM was done. On the other hand, Banjac et al. (2017) reported even better relative protein enrichment $(41.4 \%)$ of SFM, but with a lower fraction yield (around 11\%) of improved fraction in comparison to both fractionation processes conducted in this study. Regarding the results of this study, the applied fractionation processes seems to be useful in increasing the nutritional potential of SFM, turning it into the acceptable feed ingredient for monogastric animals such as swine and poultry. In addition, both studied methods were able to render fractions with high yields and still provide a protein content of fraction higher than $40 \%$ (as is), and as such fulfil the protein requirements for high protein SFM outlined in the national Regulation on animal feed quality (2010). However, the potential advantage of the sieving method is the possibility to change the opening size of the sieve used, in order to vary yield of the enriched fraction at the expense of its protein content. This way, it is possible to obtain fractions with higher yields and protein content that still correspond to the criteria of current regulation for high protein SFM, which could be of serious importance for potentially wider industrial application of this process.

\section{CONCLUSIONS}

Both processes, air classification and sieving, were capable to improve the protein content of the starting SFM to a level sufficient to categorize the meal as highprotein SFM according to the national Regulation on Animal Feed Quality (2010). The highest protein content and fraction yield for air classification as a separation step were noticed when air flow of $7 \mathrm{~m}^{3} / \mathrm{h}$ was used (42.85 and $56.42 \%$, respectively). On the other hand, separation by sieving process provided even higher protein content of conjoined $\mathrm{S}_{2}-\mathrm{S}_{4}$ fraction $(48.81 \%)$ but also somewhat lower fraction yield of $51.17 \%$. However, the fractionation process with sieving as a separation step may be optimized by applying the sieves with larger aperture. This way it is possible to obtain an optimal ratio of increased fraction yield and satisfactory protein content, which potentially leaves space for further investigations.

\section{ACKNOWLEDGEMENTS}

This paper is a result of the research within the project III46012 "Investigation of contemporary biotechnological processes in animal feed production aimed at increasing food competitiveness, quality, and safety", financed by the Ministry of Education, Science and Technological Development of Republic of Serbia.

\section{REFERENCES}

1. Aiking, H. (2011). Future protein supply. Trends in Food Science and Technology, 22 (2-3), 112120.

2. AOAC (1998). Official Methods of Analysis of AOAC international, $16^{\text {th }}$ Ed., AOAC International, Gaithersburg, MD, USA.

3. ASAE (2003). Method of determining and expressing fineness of feed materials by sieving. Standard 319.3, American Society of Agricultural and Biological Engineers, 202-205.

4. Banjac, V.V., Čolović, R.R., Vukmirović, Đ.M., Sredanović, S.A., Čolović, D.S., Lević, J.D., Teodosin, S.J. (2013). Protein enrichment of sunflower meal by air classification. Food and Feed Research, 40 (2), 77-83.

5. Banjac, V., Čolović, R., Tomičić, Z., Popović, S., Kokić, B., Vidosavljević, S., Đuragić, O. (2018). Amino acid composition and technical quality of air classified high protein sunflower meals. $8^{\text {th }}$ International Symposium "Feed Technology", Novi Sad, Serbia, Proceedings, pp. 42-47.

6. Banjac, V., Pezo, L., Pezo, M., Vukmirović, Đ., Čolović, D., Fišteš, A., Čolović, R. (2017). Optimization of the classification process in the zigzag air classifier for obtaining a high protein sunflower meal-Chemometric and CFD ap- 
Strahinja Ž. Vidosavljević et al., Comparison of two dry fractionation processes for protein enrichment of sunflower meal, Food and Feed Research, 46 (2), 209-217, 2019

proach. Advanced Powder Technology, 28 (3), 1069-1078.

7. Boye, J., Zare, F., Pletch, A. (2010). Pulse proteins: Processing, characterization, functional properties and applications in food and feed. Food Research International, 43 (2), 414431.

8. Canibe, N., Pedrosa, M.M., Robredo, L.M., Bach Knudsen, K.E. (1999). Chemical composition, digestibility and protein quality of 12 sunflowers (Helianthus annuus L) cultivars. Journal of the Science of Food and Agriculture, 79 (13), 1775-1782.

9. Cromwell, G.L. (1999). Soybean Meal-The "Gold Standard". The Farmer's Pride, KPPA News, 11 (20).

10. Dale, N. (1996). Variation in feed ingredient quality: oilseed meals. Animal Feed Science and Technology, 59 (1-3), 129-135.

11. Đorđević, N., Dinić, B. (2011). Proizvodnja smeša koncentrata za životinje. Institut za krmno bilje Kruševac, Srbija.

12. Draganov, L.K. (2015). New process for preparing high protein sunflower meal fraction. European Patent EP 2848128 A1.

13. Geneau-Sbartaï, C., Leyris, J., Silvestre, F., Rigal, L. (2008). Sunflower cake as a natural composite: composition and plastic properties. Journal of Agricultural and Food Chemistry, 56 (23), 11198-11208.

14. Green, S., Kiener, T. (1989). Digestibilities of nitrogen and amino acids in soya-bean, sunflower, meat and rapeseed meals measured with pigs and poultry. Animal Science, 48 (1), 157-179.

15. ISO 2591-1:1998 (1998). Test sieving-Part 1: Methods using test sieves of woven wire cloth and perforated metal plate, International Organization for Standardization, Geneva, Switzerland.

16. Jayasena, V., Chih, H.J., Nasar-Abbas, S.M. (2011). A practical and economical approach to efficient isolation of lupin protein. Food Australia, 63 (7), 306-309.

17. Kachrimanidou, V., Kopsahelis, N., Alexandri, M., Strati, A., Gardeli, C., Papanikolaou, S., Komaitis, M., Kookos, I.K., Koutinas, A.A. (2015). Integrated sunflower-based biorefinery for the production of antioxidants, protein isolate and poly (3-hydroxybutyrate). Industrial Crops and Products, 71, 106-113.

18. Kim, S.W., Less, J.F., Wang, L., Yan, T., Kiron, V., Kaushik, S.J., Lei, X.G. (2019). Meeting global feed protein demand: challenge, opportunity, and strategy. Annual Review of Animal Biosciences, 7, 221-243.

19. Laudadio, V., Bastoni, E., Introna, M., Tufarelli, V. (2013). Production of low-fiber sunflower (Helianthus annuus L.) meal by micronization and air classification processes. CyTA-Journal of Food, 11 (4), 398-403.

20. Lević, J., Sredanović, S. (1997). Possible ways for production of protein and other feedstuffs from plant materials. $7^{\text {th }}$ International Symposium "Advances in Feed Technology", Tara, Serbia, Proceedings, pp. 17-35.
21. Lovatto, N.M., Goulart, F.R., Loureiro, B.B., Speroni, C.S., Bender, A.B., Giacomini, S.J., Neto, J.R. Silva, L.P. (2017). Crambe (Crambe abyssinica) and sunflower (Helianthus annuus) protein concentrates: production methods and nutritional properties for use in fish feed. Annals of the Brazilian Academy of Sciences, 89 (3), 2495-2504.

22. Maaroufi, C., Melcion, J.P., De Monredon, F., Giboulot, B., Guibert, D., Le Guen, M.P. (2000). Fractionation of pea flour with pilot scale sieving. I. Physical and chemical characteristics of pea seed fractions. Animal Feed Science and Technology, 85 (1-2), 61-78.

23. Mérida, S.N., Tomás-Vidal, A., Martínez-Llorens, S., Cerdá, M.J. (2010). Sunflower meal as a partial substitute in juvenile sharpsnout sea bream (Diplodus puntazzo) diets: amino acid retention, gut and liver histology. Aquaculture, 298 (3-4), 275-281.

24. Pandya, T.S., Srinivasan, R. (2012). Effect of hammer mill retention screen size on fiber separation from corn flour using the Elusieve process. Industrial Crops and Products, 35 (1), 3743.

25. Ramachandran, S., Singh, S.K., Larroche, C., Soccol, C.R., Pandey, A. (2007). Oil cakes and their biotechnological applications-A review. Bioresource Technology, 98 (10), 2000-2009.

26. Regulation on Animal Feed Quality (2010). Pravilnik o kvalitetu hrane za životinje. Službeni glasnik RS, 4/2010, 113/2012, 27/2014, 25/2015, 39/2016, 54/2017.

27. Schutyser, M.A.I., Van der Goot, A.J. (2011). The potential of dry fractionation processes for sustainable plant protein production. Trends in Food Science and Technology, 22 (4), 154-164.

28. Senkoylu, N., Dale, N. (1999). Sunflower meal in poultry diets: a review. World's Poultry Science Journal, 55 (2), 153-174.

29. Sredanovic, S. (2007). Advancement of technological process and quality of sunflower meal, M.Sc. Thesis, Faculty of Technology, University of Novi Sad, Serbia.

30. Sredanović, S., Lević, J., Đuragić, O. (2011). Upgrade of sunflower meal processing technology. Helia, 34 (54), 139-146.

31. Srinivasan, R., To, F., Columbus, E. (2009) Pilot scale fiber separation from distillers dried grains with solubles (DDGS) using sieving and air classification. Bioresource Technology,100 (14), 3548-3555.

32. STATISTICA (Data Analysis Software System) (2018). v.13.5.0.17, TIBCO Software Inc. (http://tibco.com).

33. (SORS) Statistical Office of the Republic of Serbia (2019). Crop production. Search engine. (Retrieved Sept. 16, 2019 from http://data.stat.gov.rs/Home/Result/130102?lan guageCode=en-US)

34. Tabtabaei, S., Vitelli, M., Rajabzadeh, A.R., Legge, R.L. (2017). Analysis of protein enrichment during single-and multi-stage triboelectrostatic bioseparation processes for dry fractionation of legume flour. Separation and Purification Technology, 176, 48-58. 
35. Taelman, S.E., De Meester, S., Van Dijk, W. da Silva, V., Dewulf, J. (2015). Environmental sustainability analysis of a protein-rich livestock feed ingredient in The Netherlands: Microalgae production versus soybean import. Resources, Conservation and Recycling, 101, 61-72.

36. Wang, J., Zhao, J., De Wit, M., Boom, R.M., Schutyser, M.A. (2016). Lupine protein enrich- ment by milling and electrostatic separation. Innovative Food Science and Emerging Technologies, 33, 596-602.

37. Yasothai, R. (2016). Antinutritional factors in soybean meal and its deactivation. International Journal of Science, Environment and Technology, 5 (6), 3793-3797.

\title{
ПОРЕЪЕЊЕ ДВА ПРОЦЕСА СУВОГ ФРАКЦИОНИСАҢА У ЦИЉУ ДОБИЈАЊА СУНЦОКРЕТОВЕ САЧМЕ СА ПОВЕЋАНИМ САДРЖАЈЕМ ПРОТЕИНА
}

\author{
Страхиња Ж. Видосављевић* ${ }^{1}$, Немања Ђ. Бојанић ${ }^{2}$, Виктор Ђ. Стојков ${ }^{1}$, Радмило Р. Чоловић ${ }^{1}$, \\ Оливера М. Ђурагић ${ }^{1}$, Александар 3. Фиштеш ${ }^{2}$, Војислав В. Бањац ${ }^{1}$ \\ ${ }^{1}$ Универзитет у Новом Саду, Научни институт за прехрамбене технологије у Новом Саду, \\ 21000 Нови Сад, Булевар цара Лазара бр. 1, Србија \\ ${ }^{2}$ Универзитет у Новом Саду, Технолошки факултет Нови Сад, 21000 Нови Сад, \\ Булевар цара Лазара бр. 1, Србија
}

Сажетак: Сунцокретова сачма, споредни производ екстракције уља из сунцокретовог семена, представља важан извор протеина у домаћој и европској производњи хране за животиње. Постоји огроман интерес за бољим искоришћењем сунцокретове сачме као и за развијањем ефикасног процеса фракционисања у циљу њеног нутритивног побољшања. Ова студија предлаже и пореди два процеса сувог фрракционисања за побољшање садржаја протеина у сунцокретовој сачми на лабораторијском нивоу. Прва фраза у оба процеса обухватала је поступак двостепеног млевења коришћењем млина чекићара и млина са ваљьима. У другој фрази, тако уситњена сачма фракционисана је просејавањем или ваздушном класификацијом. Резултати су показали да је коришћењем било којег од предложених процеса могуће повећати садржај протеина сунцокретове сачме до нивоа потребног да се сматра високопротеинском према важећем Правилнику о квалитету хране за животиње, а да је истовремено обезбеђен принос сачме виши од $50 \%$. Ваздушна класифиикација је дала најбоље резултате када је употребљен проток вадуха од $7 \mathrm{~m}^{3} / \mathrm{h}(12.8 \%$ релативно повећање садржаја протеина, $56.42 \%$ принос фрракције). Када је у процесу фракционисања сепарација вршена просејавањем, најбољи резултат постигнут је када су фракције мање од $350 \mu \mathrm{m}$ спојене. У том случају релативно повећање протеина износило је $28.5 \%$ уз принос фрракције од $51.17 \%$. Тако висок садржај протеина (48.81\% рачунато на суву материју) спојене фракције, оставља простор за оптимизацију ове методе у циљу добијања одговарајућег односа садржај протеина - принос фракције. Применом сита са већим пречником отвора могуће је добити већи принос високопротеинске сачме, уз благо смањење садржаја протеина, што даје овом процесу фрлексибилност и потенцијал за примену у индустрији.

Кључне речи: сунцокретова сачма, садржај протеина, принос фрракције, суво фрракционисање, просејавање, ваздушна класификација

Received: 22 October 2019

Received in revised form: 15 November 2019

Accepted: 22 November 2019 